The $5^{\text {th }}$ chapter provides an illuminating analysis of the different aspects of cyber security of the era of global communication, where the attention is paid to the strategies of cyber security of the USA. The concepts of cyber security, cyber space, cyber-attack, cyber operations, cyber intrusion, net, Internet and some others are specified. The main state documents dealing with the issues of cyber security of the USA from 2003 to nowadays are also under discussion in this chapter, which give ground to make conclusions on the evolution of the strategies of cyber space in the USA. The chapter also brings evidence to the fact that ruling elite understands very well the importance of the exponential development of national cyber space for wellbeing of the United States as well as the growing threats to its cyber security. Social networks and cyber security of the individual is also discussed here, just as social networks as MySpace, FriendWise, Yahoo!, 36o, Classmates, Facebook. The issues of saving privacy on social networks, saving the right of liberty of speech are also considered here.

Finally, the 6th chapter deals with global communication in the context of sustainable development. The author discusses the history of discourse of the scientific metaphor "digital divide" and the way it entered the Ukrainian scientific and political discourse, together with the challenges and threats of the global digital divide. The focus on the tendencies, which require solutions as how to close global digital divide. Different media formats in global communication ae discussed with the aim to build a typology on how the issues of sustainable development in global information and communication space are covered.

As we see, the author provides a unique insight into the development of the complex sphere of global communication integrating different perspectives into her analysis. As a result the interested reader can built a certain idea of the world processes under development just as the research community can witness an interesting, productive, and integrative research of a relatively new field of study.

Irina Oukhvanova

\title{
Bibliography:
}

ZERNEC'KA, O.: Hlobal'na komunìkacìja. Kyjiv: Naukova dumka, 2017.

https://doi.org/10.5817/0S2019-2-9

\section{O slovanském slovosledu z diachronního pohledu}

KREJČOVÁ, E. Slovosledné změny v bulharských a srbských evangelních památkách $z$ 12. a 13. století. Spisy FF MU, sv. 450. Brno: Masarykova univerzita, 2016, 144 s., ISBN 978-80-210-8338-7. 
Publikace Slovosledné změny v bulharských a srbských evangelních památkách $z 12$. a 13. století se zabývá tématem, které z hlediska paleoslovenistiky má svou důležitost a nepochybně stojí za pozornost. Jde o neprozkoumanou stránku staroslověnských (i pozdějších církevněslovanských) památek, která registruje vznik nejstarších individuálních jazykových rysů ve slovosledu bulharštiny a srbštiny. Autorka se ve svém výzkumu zaměřila na zkoumání změn slovosledu v bulharských evangelních textech z 12. a 13. století, jmenovitě textech Dobromirova, Banického, Dobrejšova, Kjustendilského a Vračanského evangelia - památek z tzv. stř́edobulharského období (12.-14. století), a spolu s nimi zkoumala též srbské středověké památky - Miroslavovo a Grigorovičovo evangelium, jež z jazykového hlediska představují srbskou redakci církevní slovanštiny. Autorka porovnává texty jednotlivých evangelních přepisů jak s textem řecké předlohy, tak se staroslověnským zněním př́slušného verše slovosledné změny ve všech zkoumaných památkách jsou registrovány jako varianty $\mathrm{k}$ textu staroslověnské památky zvané Mariánské čtveroevangelium. Při zkoumání uvedených evangelních textů autorka sleduje, na základě jakých slovosledných principů je organizován slovosled v památkách ze 12. a 13. století a jestli se v něčem liší (a pokud ano, v čem) od slovosledu staroslověnských památek a řeckého originálu.

V knize autorka hledá (a úspěšně nachází) odpověd na otázku, zdali se slovosled v těchto mladších památkách vyznačuje nějakými novějšími jazykovými rysy, zdali jsou př́tomny prríznaky pronikání nějakých nových slovosledných modelů nebo zda se zachovávají rysy archaičtější. Svoji pozornost také zaměřuje na to, jestli se v těchto textech zachovávají takové slovosledné modely, které jim přisuzují znaky vyššího stylu. Na základě srovnání jednotlivých evangelních památek autorka uvádí, který text se vyznačuje poměrným konzervatismem co se pořádku slov týče a ve kterém se naopak projevují progresivnější slovosledné modely. Velmi přehledný a cenný je i vypracovaný statistický přehled všech transformací, kde E. Krejčová třídí jednotlivé doklady provedených slovosledných změn do různých skupin podle toho, čím (jakou slovoslednou tendencí) byly pravděpodobně způsobeny. Cenným autorským přínosem je zde zjištění, že v některých případech dochází ke kolizi několika principů organizace pořádku slov a následná analýza toho, který slovosledný činitel měl na slovosled větší vliv. Autorka upozorňuje také na zajímavý fakt, že některé archaické slovosledné modely se vyskytují v slovanském textu, aniž by byly př́tomny $\mathrm{v}$ řecké předloze, a vysvětluje možnou motivaci $\mathrm{k}$ použití právě takového modelu místo jiného, bezpř́znakového.

Způsob, kterým je materiál zkoumán, představuje důkladnou analýzu a interpretaci jednotlivých dokladů prizmatem klasického deskriptivismu v kombinaci s komparativní a typologickou metodou. Samotná koncepce publikace a její struktura je dobře patrná z uvedeného obsahu knihy, kde je důsledně sledován vývoj jednotlivých pozic vzájemně propojených větných členů. Text je rozdělen do šesti kapitol, které 
sledují princip regresivního řazení větných členů (kapitola 1), tendenci ke kontaktní posloupnosti větných členů (kapitola 2), aktuální členění větné (kapitola 3), rytmické faktory (kapitola 4), stylistické faktory (kapitola 5) a další slovosledné změny (kapitola 6). V závěru autorka důsledně charakterizuje každý z analyzovaných rukopisů s ohledem na slovosledné změny a odchylky od řecké předlohy. Téma je zpracováno v dostatečné šiři a hloubce, s podrobnou argumentací jednotlivých stanovisek. Rozsah kapitol je přiměřený analyzovanému jazykovému materiálu a rozsah textu podává úplný přehled jazykových dat.

Je potřeba zdůraznit, že v obsahovém plánu text knihy odpovídá stavu výzkumu v oblasti paleoslovenistiky a organicky ho doplňuje. Autorka se opírá o nejdůležitější práce v oblasti slovanské syntaxe - jak české, tak bulharské, srbské, chorvatské a také badatelů z dalších zemí (bibliografie na konci knihy má 113 položek). Citovaná literatura odpovídá tématu publikace jak obsahově, tak i svým významem jako dosažená úroveň vědeckého poznání v této oblasti. Práce je napsána jasným vědeckým jazykem a s precizními formulacemi jako logicky a stylisticky naprosto koherentní text.

Publikace přináší zásadně nové poznatky $\mathrm{v}$ oblasti slovosledu bulharských a srbských památek z 12. a 13. století ve srovnání s památkami staroslověnskými. Tím obohacuje představu o struktuře slovanské věty, která byla soustavně zkoumána pouze v časové rovině současnosti. Autorka provádí kompetentní analýzu rukopisů a formuluje vlastní závěry, které z ní plynou. Vyjadřuje své stanovisko s ohledem na základní problémy historie obou jazyků ve srovnání se situací, kterou nám dokládá tak důležitá staroslověnská památka, jakou je Codex Marianus. Je třeba si též uvědomit technickou náročnost při prrípravě publikace vzhledem $\mathrm{k}$ četným příkladům ve staroslověnštině a byzantské řečtině a ocenit bezchybnost zpracování tohoto aspektu.

Práce je přínosná a velmi podnětná i pro další výzkum a dokazuje autorčinu hlubokou znalost problematiky. Posuzovanou publikaci ocení logicky zejména odborná obec paleoslavistická.

Margarita Mladenovová

\section{Bibliography:}

KREJČOVÁ, E. Slovosledné změny v bulharských a srbských evangelních památkách $z$ 12. a 13. století. Brno: Masarykova univerzita, 2016. 